\title{
Cyanogen Bromide
}

National Cancer Institute

\section{Source}

National Cancer Institute. Cyanogen Bromide. NCI Thesaurus. Code C402.

An inorganic compound used as a reagent in molecular biology. As a reagent for peptide mapping and amino acid sequence analysis, cyanogen bromide hydrolyzes peptide bonds at methionine residues in peptides and proteins. In addition, this agent acts as a coupling reagent for phosphoramidate or pyrophosphate inter-nucleotide bonds in DNA duplexes. $(\mathrm{NCl})$ 